\title{
Eosionphilic oesophagitis in Cape Town, South Africa
}

\author{
Michael Levin", Cassim Motala \\ From Food Allergy and Anaphylaxis Meeting 2011 \\ Venice, Italy. 17-19 February 2011
}

Eosinophilic oesophagitis has been described in patients from all ethnic backgrounds in studies originating in all continents apart from Africa.

A cohort of 8 patients ( 3 boys, 5 girls) identified at Red Cross Hospital during 2009-2010 is described. Average age 7 years ( $1 \mathrm{yr} 11$ months to 15 years 10 months). Ethnicity 2 caucasian, 5 mixed, 1 Black African. Age of onset: mean 3 years, median 1 year 4 months. Age of diagnosis mean 6years 3 months, median 3 years 9 months.

Time to diagnosis: mean 3 years 3 months, median 6 months, IQ range 5 months to 6 years.

Presenting symptoms in order of prevalence are reflux (7/8), long time to eat (6/8), difficult swallowing (6/8), growth failure (5/8), food refusal (5/8) and painful swallowing (4/8).

Associated atopic diseases comprised immediate food allergy (6/8), eczema (6/8), rhinitis (6/8), asthma (3/8) and urticaria $(2 / 8)$.

Total of 26 biopsy specimens, mean 3.25 per patient. Only $4 / 8$ confirmed peak eosinophil count $>15 / \mathrm{hpf}, 7 / 8$ had minor features present.

Food skin prick tests 152 (19 per patient). Positive skin tests $>=1 \mathrm{~mm} 57$ (13 per patient). The most commonly identified foods are peas, wheat, milk, egg white, banana and egg yolk.

Skin tests $>=3 \mathrm{~mm} 32$ (7 per patient). Most commonly identified foods by SPT $>3 \mathrm{~mm}$ are egg yolk, egg white, peas, soya, rye, rice, carrot and green beans.

Patch tests 167 (21 per patient). 30 positive, average of 4.3 per patient. Most commonly identified foods are beef, peanut, lamb, chicken, soy and ham.

All commenced on initiation of short course of oral steroids. All put on targeted elimination diet. All had clinical improvement. 3 controlled and acceptable

University of Cape Town, Division of Allergy, Paediatrics and Child Health, Cape Town, South Africa symptoms, 2 some symptoms and difficulties, 2 very symptomatic with poor control, 1 defaulted.

Published: 12 August 2011

doi:10.1186/2045-7022-1-S1-P26

Cite this article as: Levin and Motala: Eosionphilic oesophagitis in Cape Town, South Africa. Clinical and Translational Allergy 2011 1(Suppl 1):P26.
Submit your next manuscript to BioMed Central and take full advantage of:

- Convenient online submission

- Thorough peer review

- No space constraints or color figure charges

- Immediate publication on acceptance

- Inclusion in PubMed, CAS, Scopus and Google Scholar

- Research which is freely available for redistribution

Submit your manuscript at www.biomedcentral.com/submit

\section{() Biomed Central}

\section{Biomed Central}

